\title{
THE EFFECT OF FERTILIZERS ON CROP YIELD, FRUIT QUALITY AND PLANT NUTRITION OF ORGANICALLY GROWN STRAWBERRY (Fragaria $x$ ananassa Duch.)
}

\author{
KILIC, N. ${ }^{1 *}-$ TUREMIS, N. F. ${ }^{2}-$ DASGAN, H. Y. ${ }^{2}$ \\ ${ }^{1}$ University of Osmaniye Korkut Ata, Kadirli School of Applied Sciences, Department of \\ Organic Farming Management, Osmaniye, Turkey \\ ${ }^{2}$ University of Cukurova, Faculty of Agriculture, Department of Horticulture, Adana, Turkey \\ ${ }^{*}$ Corresponding author \\ e-mail:neslihankilic@osmaniye.edu.tr; phone: +90-536-320-9556
}

(Received 23 $3^{\text {rd }}$ Nov 2020; accepted $3^{\text {rd }}$ Mar 2021)

\begin{abstract}
This study investigated the effects of different organic fertilizer applications on yield and quality of organically grown Albion strawberry variety. The scope of the study covers the use of vermicompost, farm manure and humic-fulvic acid as fertilizer. The yield per plant (g/plant), fruit weight $(\mathrm{g}), \mathrm{pH}$ in juice, water-soluble-solids/acid ratio in juice, plant leaf area and plant nutrition were investigated. The results indicated that the differences between the applications in yield per plant were statistically significant. The higher total yields were obtained from vermicompost and humic-fulvic acid fertilizer applications with $190.61 \mathrm{~g}$ and $182.92 \mathrm{~g}$ per plant, respectively and the lowest yield was from farm manure with $95.30 \mathrm{~g}$ per plant. The biggest fruits were obtained from the vermicompost application $(18.81 \mathrm{~g})$. The difference between applications was not significant for fruit juice $\mathrm{pH}$ values. However, the highest total soluble solids (TSS)/acid ratio was obtained with 9.82 from humic-fulvic acid application. TSS/acid ratio in strawberries is an important quality criterion in determining the taste. Nitrogen, phosphorus, potassium and magnesium concentrations were found to be higher in the leaves of strawberry plants fertilized with vermicompost. The vermicompost fertilizer seems promising in organically grown strawberries nutrition.
\end{abstract}

Keywords: Organic farming, vermicompost, humic-fulvic acid, manure, low tunnel

\section{Introduction}

Strawberry (Fragaria $x$ ananassa Duch.) has a wide growing area since it can be grown in different ecological conditions. Likewise, strawberries are also very important for humans due to health and nutrition benefits. It is fruit rich in minerals and high in vitamin C. It is one of the fruits with the highest antioxidant activity with high ascorbic acid, polyphenols, anthocyanins, and flavonols it contains. Strawberry is usually in high demand by consumers regarding color, taste, aroma, and nutritional facts (Petran et al., 2017; Pradeep and Saravanan, 2018). The total amount of strawberries produced worldwide and in Turkey is increasing every year as it is cultivated in different ecological conditions and yields fruits each year. It has also become an essential part of the food processing industry and fresh consumption; strawberry provides good profit for the producer and has a high market share. According to FAO data, strawberry production worldwide was 7,636,211 tons in 2014 and increased to 8,885,028 tons in 2019. In global strawberry production, China ranks first with 3,212,814 tons in 2019, followed by the United States of America with 1,021,490 tons (Anonymous, 2021a). In this case, Turkey, where strawberry cultivation is possible in almost every region, strawberry production in the Mediterranean and Aegean regions increases day by day in terms of high yield and earliness. According to FAO data 2014-2019 strawberry production volume was on the increase in Turkey. While the total amount of strawberry production was 376,070 tons in 
2014, it rose to 486,705 tons in 2019 (Anonymous, 2021a). Nonetheless, organic strawberry production in the country is very low compared to conventional strawberry production. In 2014, the total amount 3809,4 tons; the figure only raised to 5690,2 tons in 2019 (Anonymous, 2021b). Meanwhile, in 2019, Konya ranked first (4521,3 tons) in terms of strawberry production, which was followed by Bursa (958,3 tons) (Anonymous, 2021b). Due to the rising of environmental problems resulting from inattentive tillage, pesticides, and fertilizer use over the years, interest in organic production and products increased with consumers' interest in consuming healthy products. Therefore, much researches have been conducted to increase the production quantity, quality, and market share of strawberries grown with organic methods (Pokhrel et al., 2015; Esghi and Garazhian, 2015; Petran et al., 2017; Srivastav et al., 2018; Sharma and Negi, 2019).

This study aims to introduce different organic practices with the potential to increase yield and fruit quality and contribute to the popularization of organic strawberry production in Turkey, where organic strawberry production is low. Besides the limited number of studies on vermicompost applications in organic strawberry production, it is also a new type of organic fertilizer for our country. Indeed, it was with this particular study the fertilizer mentioned above was applied in the region for the first time. Therefore, the effects of different organic fertilizer applications on yield and quality of Albion variety were investigated in strawberry cultivation.

\section{Material and Method}

\section{Material}

Turkey is located between $36^{\circ}-42^{\circ}$ north latitude and $26^{\circ}-45^{\circ}$ east longitude. It neighbors Bulgaria, Greece, and Georgia, Armenia in the west, Azerbaijan, and Iran in the east, finally Iraq and Syria in the south. It is also located in the middle belt of the northern hemisphere close to the Equator. Temperate climate conditions are prevalent, and four different seasons are observable. Osmaniye City is in Turkey's southern part and is located in the east of the Mediterranean Region and Cukurova. Although the city's climate differs in mountainous and lowland areas, the Mediterranean climate is still dominant. Although strawberries can be cultivated in almost every region of our country, this study was carried out within the framework of earliness practice with tunnel cultivation method in Osmaniye, where the Mediterranean climate prevails (Anonymous, 2021c,d). The study was carried out on the land owned by Osmaniye Korkut Ata University in 2017-2018. Albion strawberry variety was used in the study. Albion is a day-neutral variety that adapts well to regions with cool and mild climate conditions. It is also very resistant to anthracnose, verticillium, and phytophthora (Turemis and Agaoglu, 2013). As organic fertilizers, 1) liquid humic and fulvic acid its trade name "Botanica", 2) solid vermicompost its trade name "Agrosol" and 3) solid farm manure fertilizer its trade name "Eco-flora" were used in the experiment.

Liquid humic-fulvic acid fertilizer (Botanica) is rich in water-soluble plant nutrients. It contains $50 \%$ organic matter, $21.3 \%$ organic carbon, $3 \%$ total nitrogen, and $2.5 \%$ watersoluble potassium oxide $\left(\mathrm{K}_{2} \mathrm{O}\right)$, and it is rich with humic-fulvic acid (Anonymous, 2021e). Vermicompost (Agrosol) was obtained from red california culture worms. It contains $30.33 \%$ organic matter, $15.22 \%$ total (humic + fulvic) acid, $1.11 \%$ total nitrogen, $1.06 \%$, total $\mathrm{P}_{2} \mathrm{O}_{5}, 1.55 \%$ water-soluble $\mathrm{K}_{2} \mathrm{O}$ (Anonymous, 2021f). Farm manure (Ecoflora) is an organic fertilizer produced by the biological fermentation method of bovine manure with organic ingredients of vegetable origin. It contains $40 \%$ organic matter, 
$1.5 \% \mathrm{~N}, 28.2 \%$ humic and fulvic Acid, $2 \% \mathrm{~K}_{2} \mathrm{O}, 2 \% \mathrm{P}_{2} \mathrm{O}_{5}$ (Anonymous, 2021). Also, black polyethylene mulch was used as mulch material in the experiment to cover the soil surface.

\section{Method}

Fresh seedlings were used in the experiment, and soil analysis was done before the experiment. The analysis revealed that the test area's soil was clay-loamy, salt-free, and low in organic mineral (Table 1). On October 26, 2017, planting pads were prepared, and a drip irrigation pipe was placed. Following this, the area was covered with black mulch. Seedlings were planted with a triangle planting method at $30 \times 30 \mathrm{~cm}$ intervals on 7 November 2017 (Figure 1). The trail was set up to consider random parcels with 3 repetitions based on the trial pattern and 32 plants per repetition.

Table 1. Features of the trial area soil

\begin{tabular}{c|c|c}
\hline Soil Properties & Depth $\mathbf{( 0 - 2 0} \mathbf{~ c m})$ & Depth $\mathbf{( 2 0 - 4 0}$ cm) \\
\hline Texture & Clay-loam & Clay-loam \\
pH & 7.40 & 7.40 \\
Saliniy $(\%)$ & 0.02 & 0.002 \\
Lime $(\%)$ & 38.68 & 38.68 \\
Organic Matter $(\%)$ & 5.87 & 5.68 \\
$\mathrm{P}_{2} \mathrm{O}_{5}(\mathrm{~kg} / \mathrm{ha})$ & 125.6 & 109.2 \\
$\mathrm{~K}_{2} \mathrm{O}(\mathrm{kg} / \mathrm{ha})$ & 712.1 & 540 \\
$\mathrm{Ca}(\%)$ & 0.0765 & 0.0728 \\
$\mathrm{Mg}(\%)$ & 0.0533 & 0.0497 \\
$\mathrm{Na}(\%)$ & 0.0031 & 0.3327 \\
$\mathrm{Fe}\left(\mathrm{mg} \mathrm{kg}^{-1}\right)$ & 0.92 & 1.51 \\
$\mathrm{Cu}\left(\mathrm{mg} \mathrm{kg}^{-1}\right)$ & 0.55 & 0.52 \\
$\mathrm{Mn}\left(\mathrm{mg} \mathrm{kg}^{-1}\right)$ & 4.28 & 3.74 \\
$\mathrm{Zn}\left(\mathrm{mg} \mathrm{kg}^{-1}\right)$ & 9.79 & 4.10 \\
\hline
\end{tabular}
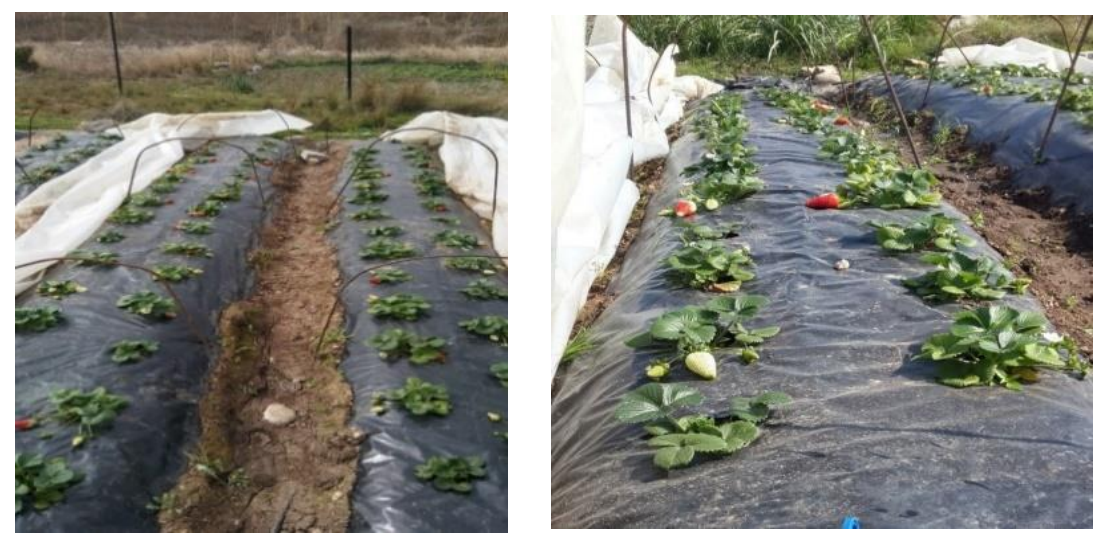

Figure 1. General view of the trial area after the planting process

In applying vermicompost and farm manure, which were solid fertilizers, the fertilizer company's recommended amount per ha was calculated per plant and then placed into the pits opened as a base fertilizer before planting. The humic-fulvic acid liquid fertilizer was 
applied as top fertilizer with drip irrigation per week. Polyethylene cover sheet was used as the low tunnel to protect the seedlings from the winter's cold.

This study included total yield per plant, fruit weight, $\mathrm{pH}$ in juice, water-solublesolids/acid ratio in juice (Kaska et al., 1986; Ozdemir et al., 2001; Adak et al., 2003) were investigated. In May, in order to investigate plant nutrition status, leaf analyzes for the concentrations of nitrogen (N) (Kacar, 1995), phosphorus (P) (Kacar, 1984), potassium $(\mathrm{K})$, calcium $(\mathrm{Ca})$, magnesium $(\mathrm{Mg})$, iron $(\mathrm{Fe})$, manganese $(\mathrm{Mn})$, zinc $(\mathrm{Zn})$ and copper $(\mathrm{Cu})$ (Kacar, 1972) were performed for 15 young leaves randomly selected from each parcel. Three plants were chosen randomly from each parcel for the leaf area analyses, and Digimizer version 5.3.5 was used for measurements. MSTAT-C package program was used in the statistical analysis of the data obtained from the research and the difference between the averages was determined according to LSD.

\section{Results and Discussion}

\section{Total Yield and Average Fruit Weight per Plant}

The results indicated that the differences between the applications in yield per plant were statistically significant. In Table 2, the higher total yield was obtained from vermicompost and humic-fulvic acid fertilizer applications with $190.61 \mathrm{~g}$ and $182.92 \mathrm{~g}$ per plant, respectively and the lowest yield was from farm manure fertilizer application with $95.30 \mathrm{~g}$ per plant. Berk (2013) reported that among the varieties "Camarosa, Kabarla, Festival, Cal Giant 3, Whitney and Sweet Charlie", with farm manure and seaweed application during the growing season, the highest amount of yield was obtained in the first year for Kabarla variety with $189.06 \mathrm{~g} /$ plant while it was for Camarosa in the second year with $94.42 \mathrm{~g} /$ plant. Eshgi and Garazhian (2015) reported the highest yield of Paros strawberry variety (150 g/plant) in humic acid application. Cay and Kaynas (2016) showed that the yield per plant was higher in the Albion strawberry cultivar with leonardite application (in the first harvest, $189.745 \mathrm{~g} / \mathrm{plant}$; in the second harvest, $176.37 \mathrm{~g} /$ plant).Weber et al. (2018) stated that applying a mixture of seaweed and $\mathrm{SiO}_{2}$ increases the total yield during applied the inflorescence and early fruit formation stage of the strawberry. In the study conducted by Srivastav et al. (2018), it was stated that the yield of organic fertilizer applications (farm manure, poultry manure, vermicompost, Azotobacter, phosphorus solublizing bacteria) in the Chandler strawberry variety was higher than the control (untreated); however, the highest two yields were obtained from the mix of all treatments (287 g/plant) and vermicompost alone (270 g/plant). Soni et al. (2018), stated that the highest yield in Sweet Charlie strawberry variety was obtained in the combined application of vermicompost, poultry manure, and Azotobacter (144.77 g/plant). While in the study of Gecer (2020) it was humic acid application yield per plant in Albion strawberry variety (146.44 g/plant), and he reported that it was higher than the control application (123.39 g/plant). The results obtained in this study are also similar to the current studies. Besides, Yadav et al. (2020) reported that the yield of Camarosa strawberry variety was $94 \mathrm{~g} /$ plant in farm manure application, $97 \mathrm{~g} / \mathrm{plant}$ in vermicompost application, and $85 \mathrm{~g} /$ plant in control. In this study, the yield values were higher than some values reported above. Therefore, results showed that yield values per plant in strawberry vary according to cultivars, applications, and ecology of the place where it is grown. 
Table 2. Effects of organic fertilizer applications on strawberry yield per plant (g/plant) and average fruit weight

\begin{tabular}{c|c|c}
\hline Applications & Yield per Plant (g/plant) & Average Fruit Weight (g) \\
\hline Humic-fulvic acid (liquid) & $182.92 \mathrm{a}$ & 16.16 \\
Vermicompost (solid) & $190.61 \mathrm{a}$ & 18.81 \\
Farm manure (solid) & $95.30 \mathrm{~b}$ & 17.53 \\
Mean & 156.28 & 17.50 \\
LSD $_{0.05}$ & 25.44 & N.S \\
\hline
\end{tabular}

The averages that differ significantly at the 5\% level according to the LSD test are shown in different letters. N.S, Not Significant

According to the results of the study on the effects of different organic fertilizer applications, the highest yield $(190.61 \mathrm{~g})$ and the biggest fruits $(18.81 \mathrm{~g})$ for the Albion strawberry variety were obtained with the application of vermicompost fertilizer (Table 2). However, there was no statistical difference between the total yields obtained from vermicompost and humic-fulvic acid applications with $190.61 \mathrm{~g}$ and $182.92 \mathrm{~g}$ per plant, respectively and the lowest yield was from farm manure fertilizer application with $95.30 \mathrm{~g}$ per plant (Table 2). Shehata et al. (2011) found that the weight of compost+mineral fertilizers applied fruits was larger (11.98 g) while Sener and Turemis (2017) observed the fruit weight of the organically grown Albion strawberry variety as $18.03 \mathrm{~g}$. Petran et al. (2017) reported the fruit weight as $14.05 \mathrm{~g}$ for the strawberries grown in the low tunnels in the city of St Paul and as $18.25 \mathrm{~g}$ for the ones in the city of Morris. Soni et al. (2018) reported that in Sweet Charlie strawberry cultivar, the maximum fruit weight was obtained by applying vermicompost, poultry manure, and azotobacter together (11.83 g). Cabiloski et al. (2014) reported no difference among applications in terms of fruit weight in their study. Strawberry fruit size is a kind of feature, besides the fertilizers environmental conditions, day and night temperature differences could also be effective.

\section{pH in Strawberry Fruit}

Fruit juice $\mathrm{pH}$ values are given in Table 3 below. The difference between applications was not statistically significant regarding organic fertilizer applications, as fruit juice $\mathrm{pH}$ values varied between 3.55 and 3.65. Gulbag and Ilgin (2016) reported that in organic strawberry cultivation $\mathrm{pH}$ values of fruit varied in the range of 3.21 and 3.37. Sener and Turemis (2017) reported that the $\mathrm{pH}$ values of organic fertilizer applications Monterey, Albion, Aromas, Camarosa, Sweet Charlie strawberry varieties varied between 3.59 and 3.83. Hoehne et al. (2018) reported the $\mathrm{pH}$ value of the Camarosa strawberry variety varied between 3.59 and 3.95. The difference among the applications in terms of $\mathrm{pH}$ values of fruits is reported to be insignificant (Berk, 2013; Gecer, 2020).

\section{Total Soluble Solids (TSS)/ Titratable Acidity Ratio in Strawberry Fruit}

TSS/acid ratios of different organic fertilizer applications were statistically significant. The highest TSS/acid ratio was obtained with 9.82 in humic-fulvic acid liquid fertilizer application. TSS/acid ratio values obtained in the experiment varied in the range of 8.79-9.82 (Table 3). In Sonata strawberry variety, as a result of two solid and two liquid fertilizer application, TSS/acid ratio (8.5-9.0 at $56^{\text {th }}$-day harvest; $10.7-11.3$ at $76^{\text {th }}$-day 
harvest) was higher than inorganic application ( 8.5 at $56^{\text {th }}$ day; 10.5 at $76^{\text {th }}$-day harvest) (Pokhel et al., 2015). The findings obtained in this study are in accordance with the study mention above. TSS/acid ratio in strawberries is an important quality criterion in determining the taste. Regarding the applications, the highest taste content was obtained in the humic-fulvic acid liquid fertilizer application. The high TSS/acid value in the study may have been due to the slower progression of the fruit ripening process in low tunnel cultivation conditions with humic-fulvic acid liquid fertilizer application's positive effect.

Table 3. Effects of organic fertilizer applications on strawberry fruit $\mathrm{pH}$ and total soluble solids (TSS) / titratable acidity

\begin{tabular}{c|c|c}
\hline Applications & pH & TSS/Titratable acidity \\
\hline Humic-fulvic acid (liquid) & 3.55 & $9.82 \mathrm{a}$ \\
Vermicompost (solid) & 3.63 & $8.79 \mathrm{~b}$ \\
Farm manure (solid) & 3.65 & $8.96 \mathrm{~b}$ \\
Mean & 3.61 & 9.19 \\
LSD $_{0.05}$ & N.S & 0.61 \\
\hline
\end{tabular}

The averages that differ significantly at the $5 \%$ level, according to the LSD test, are shown in different letters. N.S, Not Significant, humic-fulvic acid was applied to vermicompost and manure applications from above

\section{Plant Nutrient Analysis in Strawberry Leaf}

Macro nutrients as nitrogen, phosphorus, potassium, calcium, and magnesium amount of different organic fertilizer applications were provided in Table 4. The concentrations of nitrogen and potassium in the leaf was statistically significant, while it was not the case for the amount of phosphorus, calcium, and magnesium. The nitrogen concentration $(2.01 \%)$ of strawberry leaves of the vermicompost was higher than other applications.

Table 4. Effects of organic fertilizers on nitrogen $(N)$, phosphorus $(P)$, potassium $(K)$, calcium $(\mathrm{Ca})$ and magnesium $(\mathrm{Mg})$ concentarions of strawberry leaves $(\%)$

\begin{tabular}{c|c|c|c|c|c}
\hline Applications & $\mathbf{N}$ & $\mathbf{P}$ & $\mathbf{K}$ & $\mathbf{C a}$ & $\mathbf{M g}$ \\
\hline Humic-fulvic acid (liquid) & $1.85 \mathrm{ab}$ & 0.50 & $0.65 \mathrm{~b}$ & 0.96 & 0.65 \\
Vermicompost (solid) & $2.01 \mathrm{a}$ & 0.73 & $1.36 \mathrm{a}$ & 1.16 & 0.74 \\
Farm manure (solid) & $1.72 \mathrm{~b}$ & 0.60 & $0.75 \mathrm{~b}$ & 1.20 & 0.67 \\
Mean & 1.86 & 0.61 & 0.92 & 1.10 & 0.68 \\
LSD $_{0.05}$ & 0.18 & $\mathrm{NS}$ & 0.10 & $\mathrm{NS}$ & $\mathrm{NS}$ \\
\hline
\end{tabular}

The averages that differ significantly at the 5\% level, according to the LSD test, are shown in different letters. NS, Not Significant

Sener and Türemis (2016), in their study on organic strawberry cultivation, found that the nitrogen concentration of the Albion strawberry variety was $2.54 \%$, Pritts (2015) found that the nitrogen adequacy concentration in the leaf was between 2.0-2.8\% . Tagliavini et al. (2004) stated that the limit concentration of nitrogen in the leaf is between $0.9-2.02 \%$. Findings in our study also show that nitrogen concentration is sufficient.

The study observed that the leaf phosphorus concentration was between $0.50-0.73 \%$. Hassan (2015), in a study investigating the effects of organic, inorganic, and biofertilizer applications in different ratios in Sweet Charlie strawberry variety, reported that the 
phosphorus value in $100 \%$ compost application was $0.56 \%$ in $2011 / 2012$ and $0.51 \%$ in 2012/2013. Jones et al. (1991) stated that the leaf's phosphorus adequacy level was between $0.25-1.00 \%$. The phosphorus concentration of the fertilizers applied in this study is within the limits of sufficiency and is similar to the findings of Jones et al. (1991).

The highest potassium concentration was detected in leaves (1.36\%) applied to vermicompost fertilizer. In our study, the leaf potassium value was between $0.65-1.36 \%$. Sener and Turemis (2016) found the potassium concentration of Albion strawberry variety as $1.50 \%$, Jones et al. (1991) stated that the leaf's potassium adequacy level is between 1.30-3.00\%. Considering the data obtained, the concentration t of potassium was found to be sufficient in the application of vermicompost $(1.36 \%)$, while it was inadequate in humic-fulvic acid liquid fertilizer $(0.65 \%)$ and farm manure fertilizer application $(0.75 \%)$.

Leaf calcium concentration in present study was found to be in the range of $0.96-1.20 \%$. Pritts (2015) found that the calcium adequacy concentration in the leaf was between $0.7-1.7 \%$. The calcium concentration of fertilizers applied in this study is also within the limits of sufficiency.

In Table 4, it is seen that the total magnesium values in the leaf are in the range of $0.65-0.74 \%$. Jones et al. (1991) stated that the leaf's magnesium adequacy concentration is between $0.25-1.00 \%$. In this study, it can be said that the total magnesium concentration of the leaves is sufficient.

In Table 5, differences regarding the concentration of iron and zinc in the leaf were statistically significant, while it was statistically insignificant for the concentration of manganese and copper. The highest concentration of iron was measured on the leaves of strawberries with solid farm manure $(127.67 \mathrm{ppm})$, and the lowest was on the leaves of strawberries with vermicompost with $70 \mathrm{ppm}$. Jones et al. (1991) reported that the concentration of leaf iron in strawberries was sufficient between 50-200 ppm. The leaf iron concentration we obtained in the study is sufficient.

Table 5. Effects of organic fertilizers on iron (Fe), manganese (Mn), zinc ( $\mathrm{Zn})$, and copper $\mathrm{C} \mathrm{Cu}$ ) concentarions of strawberry leaves $(\mathrm{mg} / \mathrm{L})$

\begin{tabular}{c|c|c|c|c}
\hline Applications & Fe & Mn & Zn & Cu \\
\hline Humic-fulvic acid (liquid) & $92.33 \mathrm{ab}$ & 54.00 & $16.00 \mathrm{a}$ & 3.67 \\
Vermicompost (solid) & $70.00 \mathrm{~b}$ & 37.00 & $13.00 \mathrm{~b}$ & 2.67 \\
Farm manure (solid) & $127.67 \mathrm{a}$ & 63.00 & $13.67 \mathrm{~b}$ & 2.67 \\
Mean & 96.67 & 51.33 & 14.22 & 3.00 \\
LSD $_{0.05}$ & 44.44 & NS & 1.20 & NS \\
\hline
\end{tabular}

The averages that differ significantly at the 5\% level, according to the LSD test, are shown in different letters. NS, not significant

The highest concentration of zinc was obtained from a humic-fulvic acid liquid fertilizer application (16 ppm). It is determined that the total concentration of zinc in the leaf is 13 ppm-16 ppm. In his study, Jones et al. (1991) reported that the leaf's zinc adequacy concentration was between $20 \mathrm{ppm}$ and $200 \mathrm{ppm}$. The total zinc value in the leaf we obtained in this study was insufficient in all applications.

The concentration of manganese in the leaf varies between $37 \mathrm{ppm}$ and $63 \mathrm{ppm}$. Jones et al. (1991), Pritts (2015) stated that the leaf's manganese proficiency concentration is between $50 \mathrm{ppm}$ and $200 \mathrm{ppm}$. When the data obtained were evaluated, the concentration amount of manganese in the leaf was found sufficient in humic-fulvic acid liquid fertilizer 
(54 ppm) and solid farm manure (63 ppm) and insufficient in vermicompost (37 ppm). The study determined that the leaf's total copper concentration was in the range of $2.67 \mathrm{ppm}-3.67 \mathrm{ppm}$. Jones et al. (1991) reported that the copper proficiency concentration was between $6 \mathrm{ppm}$ and $50 \mathrm{ppm}$. When the data obtained were evaluated, the concentration of copper was insufficient in all applications.

\section{Effects of Organic Fertilizer on Leaf Area ( $\mathrm{cm}^{2} /$ plant)}

Leaf area results are given in Table 6, and it was observed that the effect of all applications on leaf area was found statistically insignificant. Leaf area values were between 529.10 and $649.10 \mathrm{~cm}^{2} /$ plant. Eshghi and Garazhian (2015) reported that in the Paros strawberry variety, the maximum leaf area in the humic acid application they applied at different rates through the leaf and the soil was $533.4 \mathrm{~cm}^{2} /$ plant as a result of the leaf application $\left(900 \mathrm{mg} / \mathrm{L}^{-1}\right)$. Alkharpotly et al. (2017) reported that the leaf area varied between $295.9 \mathrm{~cm}^{2} /$ plant $-566.6 \mathrm{~cm}^{2} /$ plant in 2014/2015 and between $311.2 \mathrm{~cm}^{2} /$ plant $-614.2 \mathrm{~cm}^{2} /$ plant in 2015/2016 in different doses of humic acid and seaweed applications in Festival strawberry variety. Srivastav et al. (2018) reported that in the Chandler strawberry variety, organic and bio-fertilizer applications (farm manure, poultry manure, and vermicompost) yielded higher leaf area compared to control (untreated). The widest leaf area was obtained in the combined application of vermicompost and biofertilizers. The leaf area values in this study are close to the leaf area values of the studies above. However, strawberry leaf area varies based on the cultivars, different types of applications, and the place's ecology where it is grown.

Table 6. Effects of organic fertilizers on strawberry plant leaf area $\left(\mathrm{cm}^{2} / \mathrm{plant}\right)$

\begin{tabular}{c|c}
\hline Applications & Leaf area \\
Humic-fulvic acid (liquid) & 649.10 \\
Vermicompost (solid) & 529.10 \\
Farm manure (solid) & 595.89 \\
Mean & 591.36 \\
LSD $_{0.05}$ & NS \\
\hline
\end{tabular}

The averages that differ significantly at the $5 \%$ level according to the LSD test are shown in different letters. N.S, Not Significant

\section{Conclusion}

Strawberry is a very popular fruit. The organic nature of the strawberry becomes much more attractive and is in high demand by the consumer.

It has been determined that vermicompost and humic-fulvic acid fertilizers are effective in organic strawberry cultivation to obtain high yield. The largest fruits were detected from the vermicompost application. The total soluble solids/ titratable acidity ratio was higher in the humic-fulvic acid application. Considering plant nutrient analysis, it was seen that the amount of nitrogen, phosphorus, calcium, magnesium, and iron was sufficient while the amount of zinc and copper was insufficient in all three different organic fertilizers, namely; vermicompost, humic-fulvic acid liquid fertilizer, and farm manure. While the potassium amount was found to be sufficient in the application of vermicompost, it was found insufficient in humic-fulvic acid liquid fertilizer and farm manure. 
The vermicompost fertilizer seems promising in organically grown strawberries nutrition. In future studies, it is recommended to use solid and liquid forms of vermicompost fertilizers together to increase organic yield and product quality in strawberries, and apply the liquid form via dripping or on the foliage, and try with new biofertilizers.

\section{REFERENCES}

[1] Adak, N., Gubbuk, H., Pekmezci, M. (2003): The growing possibilities of some strawberry cultivars grown under protected cultivation in Antalya conditions (Bazı çilek çeşitlerinin Antalya koşullarında örtü altında yetiştirme olanakları üzerinde araştırmalar). - Turkey IV. National Horticulture Congress Antalya, pp. 313-315.

[2] Alkharpotly, A. A., Mohamed, R. A., Shehata, N. M., Award, A. A. M. (2017): Impact of soil humic acid soil application and seaweed extract foliar spray on growth, yield, and fruits quality of strawberry plants grown under Aswan conditions. - Mansoura Univ., J. Soil Sci. and Agric. Eng. 8(6): 307-315.

[3] Anonymous (2021a): http://www.fao.org/faostat/en/\#data/QC/visualize.

[4] Anonymous (2021b): https://www.tarimorman.gov.tr.

[5] Anonymous (2021c): https://www.cografyaci.gen.tr/.

[6] Anonymous (2021d): https://osmaniye.ktb.gov.tr/TR-60790/cografya.html.

[7] Anonymous (2021e): https://www.camli.com.tr/urun/camli-botanica.

[8] Anonymous (2021f): http://agrosolgubre.com/urun/agrosol-granul-gubre.

[9] Anonymous (2021g): http://www.ekofarm.com.tr/ekoflora.html.

[10] Berk, S. (2013): Determination of yield and quality characteristics of some strawberries cultivars grown organically in Bolu (Mudurnu) ecological conditions (Bolu (Mudurnu) ekolojik koşullarında organik olarak yetiştirilen bazı çilek çeşitlerinin verim ve kalite özelliklerinin belirlenmesi). - Journal of Agricultural Science Research 6(1): 68-72. www.nobel.gen.tr.

[11] Cabilovski, R., Manojlovic, M., Bogdanovic, D., Magazin, N., Keserovic, Z., Sitaula, B. (2014): Mulch type and application of manure and composts in strawberry (Fragaria $\times$ ananassa Duch.) production: impact on soil fertility and yield. - Zemdirbyste-Agriculture 101(1): 67-74. DOI: 10.13080/z-a.2014.101.009.

[12] Cay, S., Kaynas, K. (2016): Albion and Sweet Ann leonardit the cultivation of strawberry cultivars effects on plant growth and yield (Leonardit uygulamasinın Albion ve Sweet Ann çilek çeşitlerinde bitki gelişimi ve verime etkileri). - COMU J. Agric. Fac. 4(1): 13-19.

[13] Eshghi, S., Garazhian, M. (2015): Improving growth, yield and fruit quality of strawberry by foliar and drench application of humic acid. - Iran Agricultural Research 34(1): 14-20.

[14] Gecer, M. K. (2020): Effect of humic acid application on fruit yield and quality in some strawberry cultivars (Humik asit uygulamalarının bazı çilek çeşitlerinin meyve verimi ve kalitesi üzerine etkileri). - International Journal of Agriculture and Wildlife Science 6(1): 21-27. DOI: 10.24180/ijaws.65453.

[15] Gulbag, F., Ilgin, M. (2016): Determination of the effects of different organic preparates on the yield, fruit quality and plant growth in some strawberry cultivars (Farklı organik içerikli preparatların bazı çilek çeşitlerinde verim ve kalite üzerine etkilerinin belirlenmesi). - BAHÇE 45 (Special issue 2): 153-161.

[16] Hassan, A. A. (2015): Effect of nitrogen fertilizer levels in the form of organic, inorganic and bio fertilizer applications on growth, yield and quality of strawberry. - Middle East $\mathrm{J}$. Appl. Sci. 5(2): 604-617.

[17] Hoehne, L., Altmayer, T., Martini, M. C., Finatto, J., Brietzke, D. T., Kuhn, D., Severo Filho, W. A. (2020): Effect of humus and soil substrates on production parameters and quality of organic strawberries. - Horticultura Brasileira 38: 101-106. 
http://dx.doi.org/10.1590/S0102-053620200116.

[18] Jones, J. R., Wolf, B., Mills, H. A. (1991): Plant Analysis Handbook. - Micro Macro Publishhing, Inc. ISBN 13: 9781878148001.

[19] Kacar, B. (1972): Chemical analysis of plant and soil: II. Plant analysis (Bitki ve toprağın kimyasal analizleri. II. Bitki analizleri). - Ankara University Faculty of Agriculture Publication No.: 453.

[20] Kacar, B. (1984): Plant nutrition application guide (Bitki besleme uygulama klavuzu). Ankara University Faculty of Agriculture Publication No.: 900.

[21] Kacar, B. (1995): Chemical analyses of plant and soil, III. Soil Analyses (Bitki ve toprağın kimyasal analizleri. III. toprak analizleri). - Ankara Üniversitesi. Zir. Fak. Eğt. Araş. ve Gel. Vakfi Yay. No.: 3.

[22] Kaska, N., Yildiz, A. I., Paydas, S., Bicici, M., Turemis, N., Kuden, A. (1986): Effects of winter and early summer plantings and shelter systems on the yield quality and early production of some new strawberry varieties for Turkey under Adana ecological conditions (Türkiye için yeni bazı çilek çeşitlerinin Adana'da yaz ve kış dikim sistemleriyle örtü altında yetiştiriciliğinin verim, kalite ve erkencilik üzerine etkileri). - Nature Science Journal 10(1): 84-102.

[23] Ozdemir, E., Gunduz, K., Bayazit, S. (2001): Determination of yield, quality and precocity of some strawberry cultivars grown under high tunnel by using fresh runners rooted in pots in Amik plain (Tüplü taze fideyle yüksek tünelde yetiştirilen bazı çilek çeşitlerinin Amik ovası koşullarında verim, kalite ve erkencilik durumlarının belirlenmesi). - Bahçe 30(1-2): 65-70.

[24] Petran, A., Hoover, E., Hayes, L., Poppe, S. (2017): Yield and quality characteristics of day-neutral strawberry in the United States Upper Midwest using organic practices. Biological Agriculture \& Horticulture 33(2): 73-88.

DOI: $10.1080 / 01448765.2016 .1188152$.

[25] Pokhrel, B., Laursen, K. H., Petersen, K. K. (2015): Yield, quality, and nutrient concentrations of strawberry (Fragaria $\times$ ananassa Duch. cv. 'Sonata') grown with different organic fertilizer strategies. - J. Agric. Food Chem. 63: 5578-5586.

DOI: 10.1021/acs.jafc.5b01366.

[26] Pradeep, B., Saravanan, S. (2018): Effect of different biofertilizers and organic manures on yield and quality of strawberry (Fragaria $\mathrm{x}$ ananassa Duch.) cv. Chandler. - Journal of Pharmacognosy and Phytochemistry 7(6): 151-155.

[27] Pritts, M. (2015): Berry soil and nutrient management: A Guide for Educators and Growers. - Chapter 6., Cornell University.

[28] Sener, S., Turemis, N. F. (2016): Effects of several cultıvars, mulch and fertilizer applications on plant growth and development criteria and plant's nutrition elements uptake in organic strawberry plantation in Nevşehir city. - Asian Journal of Agriculture and Rural Development 6(11): 221-228.

DOI: 10.18488/journal.1005/2016.6.11/1005.11.221.228.

[29] Sener, S., Turemis, N. F. (2017): Influence of mulch types on yield and quality of organically grown strawberry cultivars. - SDU Journal of the Faculty of Agriculture 12(2): 66-72.

[30] Sharma, K., Negi, M. (2019): Effect of organic manures and inorganic fertilizers on plant growth of strawberry (Fragaria $x$ ananassa) cv. Shimla delicious under mid-hill conditions of Uttarakhand. - Journal of Pharmacognosy and Phytochemistry 8(2): 1440-1444.

[31] Shehata, S. A., Gharib, A. A., El-Mogy, M. M., Abdel Gawad, K. F., Shalaby, E. A. (2011): Influence of compost, amino and humic acids on the growth, yield and chemical parameters of strawberries. - Journal of Medicinal Plants Research 5(11): 2304-2308. Available online at http://www.academicjournals.org/JMPR.

[32] Soni, S., Kanawjia, A., Chaurasiya, R., Chauhan, P. S., Kumar, R., Dubey, S. (2018): Effect of organic manure and biofertilizers on growth, yield and quality strawberry (Fragaria $\mathrm{X}$ 
ananassa Duch) cv. Sweet Charlie. - Journal of Pharmacognosy and Phytochemistry SP2: 128-132.

[33] Srivastav, A., Singh, K. B., Pandey, R., Sing, K., Singh, V. (2018): Effect of organic manures and bio-fertilizers on vegetative growth and yield of strawberry cv. Chandler. Journal of Pharmacognosy and Phytochemistry 7(5): 2841-2844.

[34] Tagliavini, M., Bald, E., Westby, R., Raynal-Lacroix, C., Lieten, P., Solo, T., Faedi, W. (2004): Uptake and partitioning of major nutrients by strawberry plants. - Acta Horticulturae 649: 197-200. DOI:10.17660/Acta Hortic.2004.649.36.

[35] Turemis, N., Ağaoğlu, Y. S. (2013): Berry Fruits, Chapter II (Üzümsü Meyveler, II. Bölüm). -Ağaoğlu, S., Gerçekcioğlu, R. (eds.) Tomurcuk Bağ Ltd. Şti. Education Publications 1: 55-100.

[36] Weber, N., Schmitzerb, V., Jakopic, J., Stampar, F. (2018): First fruit in season: seaweed extract and silicon advance organic strawberry (Fragaria $\times$ ananassa Duch.) fruit formation and yield. - Scientia Horticulturae 242: 103-109. https://doi.org/10.1016/j.scienta.2018.07.038.

[37] Yadav, P., Mishra, K. K., Yadav, K. A., Pandey, G., Kumar, V. (2020): Effect of organic manure, NPK and mulching on better growth, yield and quality of strawberry (Fragaria ananassa Duch.) cv. Camarosa. - Journal of Pharmacognosy and Phytochemistry 9(2): 1489-1495. DOI: https://doi.org/10.22271/phyto.2020.v9.i2y.11063. 